\title{
'Prosperity a part of the atonement': An interpretation of 2 Corinthians 8:9
}

\begin{tabular}{|c|}
\hline $\begin{array}{l}\text { Author: } \\
\text { Abiola Mbamalu }{ }^{1}\end{array}$ \\
\hline $\begin{array}{l}\text { Affiliation: } \\
{ }^{1} \text { Department of Biblical } \\
\text { Studies and Ancient } \\
\text { Languages, North-West } \\
\text { University, Potchefstroom } \\
\text { Campus, South Africa }\end{array}$ \\
\hline $\begin{array}{l}\text { Correspondence to: } \\
\text { Abiola Mbamalu }\end{array}$ \\
\hline $\begin{array}{l}\text { Email: } \\
\text { abiola_uzoamaka@hotmail. } \\
\text { com }\end{array}$ \\
\hline $\begin{array}{l}\text { Postal address: } \\
\text { Private Bag X6001, } \\
\text { Potchefstroom 2520, } \\
\text { South Africa }\end{array}$ \\
\hline $\begin{array}{l}\text { Dates: } \\
\text { Received: } 02 \text { Feb. } 2015 \\
\text { Accepted: } 10 \text { Aug. } 2015 \\
\text { Published: } 03 \text { Nov. } 2015\end{array}$ \\
\hline $\begin{array}{l}\text { How to cite this article: } \\
\text { Mbamalu, A., 2015, } \\
\text { “"Prosperity a part of } \\
\text { the atonement": An } \\
\text { interpretation of } 2 \\
\text { Corinthians } 8: 9 \text { ', Verbum et } \\
\text { Ecclesia } 36(1), \text { Art. \#1418, } \\
8 \text { pages. http://dx.doi. } \\
\text { org/10.4102/ve.v36i1.1418 }\end{array}$ \\
\hline $\begin{array}{l}\text { Copyright: } \\
\text { (C) 2015. The Authors. } \\
\text { Licensee: AOSIS } \\
\text { OpenJournals. This work is } \\
\text { licensed under the Creative } \\
\text { Commons Attribution } \\
\text { License. }\end{array}$ \\
\hline
\end{tabular}

Read online:

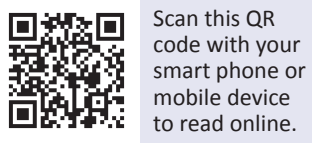

This article investigates the claim made by some Pentecostal preachers that prosperity is part of the atonement. The biblical basis that such preachers present for their claim is a specific understanding of 2 Corinthians 8:9. The phrase, $\delta 1 \alpha v \mu \alpha{ }$, is sometimes translated 'for your sakes' or 'because of you', and the verse is understood by these preachers as indicative of the vicarious nature of the poverty of Jesus. A reading of the Greek text of 2 Corinthians 8:9, however, does not lend itself to this interpretation. Furthermore, Paul's act of soliciting for funds to help the poor saints in Jerusalem makes the claim that prosperity is part of the atonement quite unwarranted by the text.

Intradisciplinary and interdisciplinary implications: The contextual perspective this work is challenging is the Neo-Pentecostal interpretation of 2 Corinthians 8:9 that prosperity is part of the atonement. This research discountenances such understanding and affirms the traditional view that the scope of the atonement of Christ does not imply financial abundance. The atonement of Christ, however, does have financial implications, for it has brought about a new community that cares for its members.

\section{Introduction}

\section{Atonement}

Discourses on atonement in literature have often revolved around the issues of the various theories of atonement. Discussion could also sometimes centre on the issue of the extent of atonement: whether it is universal, or restricted only to the elect. This is the staple one usually finds in monographs on systematic theology. Germane to the discussion of the extent of the atonement is the question: What did Jesus atone for? Scholars and believers are unanimous in their view that Jesus atoned for sins, for atonement is generally understood to refer to the 'work of Jesus in putting right the human situation in relation to God' (Tuckett 1992:518).

Erickson (1998:852) observes that in addition to the traditional belief that 'Christ's death was to remove the effects of sin, that is, guilt and condemnation, a new emphasis has emerged in the twentieth century'. Situating this new emphasis within the Pentecostal movement, particularly within Neo-Pentecostal or charismatic circles between the eighties and the nineties, Erickson observes that greater emphasis is placed on miracles of healing than in other forms of Christianity. The theological foundation of this teaching is said to be the atonement: ' ... healing, no less than forgiveness of sins and salvation, is to be found within the atonement. Christ died to carry away not only sin, but sickness as well' (Erickson 1998:853). Erickson (1998:857) notes that the view that Christ's death brings about healing arises from the understanding that the origin of illness in the world is the Fall. It is therefore reasoned that if Christ died to reverse the effect of the Fall, healing as well as forgiveness of sins, is part of the redemption accomplished by Christ. He goes on to discuss the texts pivotal for the view of healing as part of the atonement and concludes that healing is not necessarily a part of the atonement.

Erickson's discussion of the view that healing is not part of the atonement is equally applicable and relevant to the newer understanding that later emerged, namely, prosperity is part of the atonement. This new emphasis on prosperity has emerged within the same rubric of Pentecostalism and particularly in its Neo-Pentecostalism mode. Though this teaching has a global context, in this article the focus shall only be on its local understanding among some Nigerian preachers. For this reason, this article shall investigate three Nigerian preachers' depiction of prosperity as part of the atonement. Two of these preachers have churches in most countries of Africa and therefore exercise influence well beyond their immediate local Nigerian context. In addition, the influence of these preachers in Nigeria extends beyond their immediate churches given the prevalence of Pentecostal and charismatic discourse in church life in Nigeria. It is safe to surmise then that the impact of this teaching on many Christians in Africa may be quite significant. The significance 
of the teachings of these preachers for Nigeria is increased by the fact that these preachers were well acquainted with the revival that broke out in the Nigerian campuses in the seventies and therefore started life as Christians with the holiness emphasis.

\section{Pentecostalism and Neo-Pentecostalism in Nigeria}

The point of departure for this article is taken from the 1970 revival that broke out in the Nigerian Universities (Ojo 1986), for it is the immediate antecedent for Neo-Pentecostalism in Nigeria. This revival was the third epoch in charismatic manifestations in the country (Kalu 2008:88) and it had its emphasis on Jesus as saviour, sanctifier, healer, baptiser and soon coming king, while its praxis was characterised by an ascetic lifestyle (Marshall 2009:71). The link between the transition and transformation from classical Pentecostal ascetic lifestyle to Neo-Pentecostal flamboyant lifestyle is Benson Idahosa, as Kalu (2008) puts it so succinctly:

by the 1980s, his theology was developing some of the themes from T.L.Osborn as Idahosa waxed strong with prosperity motifs that sounded like music in the ears of those who had just come out from the civil war. (p. 91)

The prosperity motif has run through a whole gamut of principles: 'positive confession leads to possession', sowing seeds especially to the 'man of God' (Asamoah-Gyadu 2005:401; Marshall 2009:79), however, the theological matrix for the motif is the understanding that prosperity is part of the atonement. This is well articulated by Gifford (1998):

According to the Faith Gospel, God has met all the needs of human beings in the suffering and death of Christ, and every Christian should now share the victory of Christ over sin, sickness and poverty. A believer has a right to the blessings of health and wealth won by Christ, and he or she can obtain these blessings merely by a positive confession of faith. (p. 39)

While some scholars (Gifford 1998; Togarasei 2011) have looked at the impact of the prosperity gospel on the society, a literary cum theological analysis of the bedrock of the gospel is lacking in literature. This is what this article is out to do: it seeks to investigate the literary cum theological foundation on which the conception of prosperity as part of atonement lies.

\section{Setting the context of 2 Corinthians 8}

The second letter of Paul to the Corinthians derives from his first letter to them. Most of the issues raised in the second letter arose from, or are a continuation of the issues raised in 1 Corinthians. The letter divides neatly into three parts, namely, chapters 1-7; 8-9 and 10-13. In chapters 1-7, Paul discusses issues that border on his previous relationship with the Corinthians in terms of the discipline of an erring member, issue of an unfulfilled promise to visit the Corinthians, and a general description of the gospel and what it entails. Chapters 8-9 focus mainly on the issue of giving to the Jerusalem saints, an issue which he had earlier raised in chapter 16 of 1 Corinthians. Chapters 10-13 capture Paul's suffering in the ministry with the aim of having the Corinthians understand him and express their love for him more openly and sincerely.

Chapter 8 marks a departure from the previous discussion in chapter 7, which was about Titus' positive impression of the Corinthians' love for Paul. Yet the rhetoric is, however, not strictly a departure, for Paul is using the good impression made on Titus and his own restored confidence in them to urge them to give practical expression to their earlier commitment to give to the Jerusalem saints. The scenario is better captured by noting the last verses of chapter 7 :

\footnotetext{
... we were especially delighted to see how happy Titus was, because his spirit has been refreshed by all of you. I had boasted to him about you, and you have not embarrassed me. But just as everything we said to you was true, so our boasting about you to Titus has proved to be true as well. And his affection for you is all the greater when he remembers that you were all obedient, receiving him with fear and trembling. I am glad I can have complete confidence in you. (Cor 7:13b-16)
}

This sets the context for what was to follow. In an honourshame context of the Corinthians, it was almost impossible to disappoint someone who had expressed so much confidence in one as Paul has just done. As Malina and Neyrey (1991:26) make clear, "honor is linked with "face" ("saving face") and "respect"'. At stake is how others see us, and so, how we see ourselves'. The appeal to honour is also implicit in Paul's setting up the Macedonians as a model for the Corinthians to emulate. Belleville (1996) makes a similar observation:

Paul uses interchurch competition to spur the Corinthians toward Christlike maturity ... he also uses their fear of losing face before other churches to motivate them to give: 'I am sending the brothers in order that our boasting about you in this matter should not prove hollow' (9:3); 'if any Macedonians come with me and find you unprepared, we - not to say anything about you - would be ashamed of having been so confident' (9:4). (pp. 43-44)

\section{The rhetoric of giving in $\mathbf{2}$ Corinthians 8}

This chapter opens on a note of commendation for the Macedonian churches for their liberality in giving to the Jerusalem saints' project, by means of this, Paul sets them up as a model for the Corinthian church.

\section{The Macedonians as a model}

The Macedonians are presented as a model for the Corinthians to emulate in terms of generous giving in spite of their extreme poverty. God's grace was said to have been given to the Macedonian churches and this grace enabled them to give beyond what they could be expected to afford. Yet they gave with great joy. The Corinthians are being urged to 'excel in this grace of giving also' (8:7). Titus was to come to complete 'this act of grace' on the part of the Corinthians. In this way, the Macedonians were presented as a model for the Corinthians to emulate.

\section{Jesus as a model}

In addition to the Macedonians, Jesus is also presented as a model for the Corinthians to emulate. The parallelism 
between Jesus and the Macedonian churches is obvious: both of them are described in terms of grace, but while the grace bestowed on the Macedonian churches had to be made known to the Corinthian church, that of Jesus was what they already knew. Secondly, the verbs used in both cases are cognates: $\gamma \imath \omega \omega \sigma \omega$ and $\gamma \nu \omega \rho i \zeta \omega$. Further parallelism is seen in the fact that the words poverty and riches occur in both models:

8:1-2:

We - make known / disclose to you, brothers,

the grace of God given to the churches of Macedonia

... their extreme poverty welled up in rich generosity

8:9:

For you know the grace of our Lord Jesus Christ

That though He was rich yet for your sakes became poor

With reference to the Macedonian Christians: they were experiencing severe tribulation, they were in abject poverty yet they were richly generous. The lesson seems clear to the Corinthians: whatever the level of their poverty, it is assumed that it was not as bad as the Macedonians'; thus what was expected of them was a generous contribution that would, perhaps, surpass that of the poor Macedonian churches.

With regard to Jesus: 'Jesus was rich but because of you he became poor, so that by his poverty, you may be rich'. By the use of the present participial form of the $\varepsilon 1 \mu \mathrm{u}$ verb, Jesus in his pre-existent state is declared as rich. His poverty is a state that he assumed at a particular point in time. For this reason, scholars like Thrall (2004:534) and Belleville (1996:216) take the aorist as ingressive, thereby putting focus on the beginning of the action, the incarnation; while Harris (2005:580) chooses to take the aorist as constative, thereby viewing the action as a whole, putting into perspective Jesus' birth, suffering, death and resurrection. From these scholars, one may deduce that Jesus' poverty had a beginning, for he was not originally poor. The implication of this is that Jesus was rich in his pre-existent state. It is this state that is now held to be in contrast with his earthly state of existence, a state that was characterised by poverty. What could possibly be the nature of these riches and poverty? With regard to his riches in the pre-existent state, it is plausible to hold that the riches or wealth is not reckoned in terms of money or land or property, for such categories do not appropriately describe the state of existence in that milieu, yet it is a rich state even by human reckoning. In the corollary, the poverty which he experienced by virtue of his incarnation, suffering, death and resurrection is also understandable from human point of view as poverty. One may also hold that Jesus' poverty did entail material poverty as evinced in statements such as: '... but the son of man has no place to lay his head' (Mt 8:20); another case in point is when he had to pay the temple tax but had no money on him (Mt 17:24-27). At a practical level then, Jesus was poor materially and like the philosophers of his time lived on the goodwill of his supporters. Yet the poverty of Jesus cannot be fully accounted for only in material terms, for if his riches are often understood in terms of the glories of heaven and his unbroken fellowship with the father (Belleville 1996:216), then his poverty must transcend just physical poverty. That is, for a true contrastive parallelism to exist between Jesus' riches and poverty, we may expect that though the milieus of existence differ, the lack of what Jesus had in his pre-existent state is at least part of what constitutes his poverty in the incarnate state. It may seem then, that the dichotomy between the material and the non-material is quite artificial. Otherwise, it would not make much sense to compare the non-material riches of Jesus with his material poverty in a context where material needs are to be met concretely. Therefore, it seems reasonable to expect that the riches of the Corinthians and the poverty of Christ must converge at some point since both of them lived in the same terrestrial context.

His riches though non-material must have implications for the material, while his poverty is both material and non-material. The crux of Paul's appeal to the Corinthians is two-pronged. Firstly, the grace exhibited by Jesus (subjective genitive) made him leave his riches and take up a poor state in order to enrich the Corinthians. In this way, he serves as a model for the Corinthians to emulate in sacrificial giving. Secondly, Paul was also focusing on the riches bestowed on the Corinthians by virtue of the poverty of Jesus. The Corinthians should act with the consciousness of the riches bestowed on them and give generously, as Barnett (1997) puts it:

since we are made 'rich' by God's grace - in both salvation and gifts - the appropriate response can only be our generosity to others. This is the message of these two chapters. Grace begets grace! (p. 409)

But what is the nature of the riches of the Corinthians? To answer this question one must further ask whether the riches mentioned by Paul are peculiar to the Corinthians, or are these riches also bestowed on other believers? If the riches alluded to by Paul are shared by other believers, then the Jerusalem saints, on whose account funds was being raised, were not exempted. So the Jerusalem saints were rich in Paul's terms but poor materially, at least at that point in time. Could it be that the riches that Paul had in view were not necessarily material? But what is the use of riches that are non-material for the purpose of giving funds? The point of convergence for the riches of the Corinthians and the poverty of Jesus is perhaps in the creation of a fictive kinship relationship among believers. Kinship relationship imposes obligations on family members to care for one another. It is therefore possible to be materially poor yet rich in human and spiritual resources. The material lack experienced by a section of God's people at a particular point in time is met by the material resources of other believers - a case in point is found in Acts 2:44-45. As Belleville (1996:208) notes: '... the relief fund served as an important, visible expression of the interdependence of believers worldwide. All of life is included in the shared concerns of those in Christ'. In this case, the riches of the church are in its sense of community. 
This is alluded to in Romans 15:25-27 where Paul recounts the justification for the Gentiles' gift to the Jerusalem saints:

they were pleased to do it, and indeed they owe it to them. For if the Gentiles have shared in the Jews' spiritual blessings, they owe it to the Jews to share their material blessings.

It is also in the light of this that the desire for equality expressed in 2 Corinthians 8:13-14 may be understood:

Our desire is not that others might be relieved while you are hard pressed, but that there might be equality. At the present time your plenty will supply what they need, so that in turn their plenty will supply what you need. Then there will be equality ... (NIV)

So what is the nature of the Corinthians' riches? The Corinthians' riches, according to 2 Corinthians 8:9, are not material, they are non-material but they do have tangible and material implications. Hauck and Kasch (1968) suggest

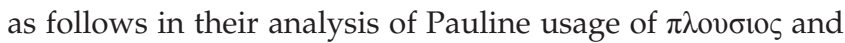
its cognates:

True riches consist in the love which expresses itself in selfsacrifice in following Jesus, which does not seek its own (I C. 13:4-13), which shows itself to be genuine by not bragging about the riches it has received, as the Corinthians did according to Paul (I C. 4:7 f), by its consequent freedom from the demonism of the world and of things, by its confidence that God will supply every need according to His riches in glory (Phil. 4:19), and therefore by having an open hand for the brethren (2 C. 8:1-10, cf. 9:6-14; authors' own italics). (p. 329)

The views of some preachers that prosperity is part of the atonement will now be discussed.

\section{Some preachers' views of prosperity as part of atonement}

In this section, the three preachers in focus are introduced and their views on prosperity as part of the atonement presented.

\section{Bishop Wale Oke}

Wale Oke, a graduate of Environmental Engineering, from the University of Lagos (Ojo 2006:163) got converted in 1975 under the auspices of the Scripture Union (SU). He later became the President of Lagos Varsity Christian Union (LVCU). Of Anglican background, he went back to the Anglican church with the Pentecostal experience but met with stiff opposition from the church's authorities and in his own words 'they kicked us out'. ${ }^{1}$ In 1983 he started an interdenominational ministry called Sword of the Spirit Ministries. In 1989, the church arm of the ministry, Christ Life Church, was inaugurated. The ministry's headquarters is at Ibadan, in the south western part of Nigeria.

\section{Bishop Wale Oke's views on prosperity}

Concerning his views on prosperity, Bishop Oke (1999) believes that it is part of the atonement. According to him, 1.Personal interview with Wale Oke on 21 January 2010 , in his office in ibadan. the blood of Jesus was shed from five major points of his body: his back, his head, his hands, his feet and his side. Blood flowed from Jesus' hands when nails pierced them as he was hung on the cross. The significance of the blood shed from Jesus' hands lies in the symbolic role of hands as the means of acquiring wealth:

Your hands are the symbol of your economic capability and strength. Your hands are used to labour and to gather wealth. You receive and give money with your hands. The Bible always talks of 'the work of your hands' or 'that which you set your hands upon to do' (Deuteronomy 28:8,12) ... You handle money with your hands. Your hands have to do with your prosperity. This is why a man who is lazy or idle shall come to poverty; but the diligent shall be made rich. ${ }^{2}$ (pp. 125-126)

Furthermore as Oke asserts (1999), Adam lost the abundance of provision he had when he fell, for the ground was cursed because of him. For this reason it would no longer give the man its full yield on cultivation, rather thorns and thistles would grow:

One crucial area where the curse that came in the fall affected man was his economy. Prior to the fall man was living in God's abundance. All he needed was freely available in the garden. He did not need to sweat in order to eat. Abundance was at his finger tips. As a matter of fact, God provided before He made man. Eden means abundance; pleasure; paradise; bliss; or delight. At the fall, man was driven out of Eden, from thenceforth to live 'out of the sweat' of his face. Prior to the fall, his land yielded superabundantly. Now, following the fall, the land 'shall no longer yield its strength'. Poverty, hardship, insufficiency and debt were direct products of the curse. The work of man's hands was cursed and his economic capability diminished. Poverty now replaced abundance. (p. 127)

Jesus, as the second Adam through whom God was making a new creation, 'through the shedding of his blood on the cross paid the price to cancel poverty and release abundance' (Oke 1999:129). Oke argues that unlike what other interpreters have said, the poverty in view here is physical and not spiritual, for Jesus can on no account be considered to be spiritually poor. Therefore, 'the abundant life that Jesus has brought for us includes financial and material prosperity'. He purchased this for believers 'by shedding that precious blood through his hands', by virtue of this 'Jesus released the covenant blessing of wealth upon your hands - the power to get and create wealth' (Oke 1999:130). In conclusion he asserts, 'poverty is an enemy that Jesus conquered on the cross by allowing his hands to be pierced to free you from its grips ... His hands were pierced that your hands may be blessed' (Oke 1999:133-134).

\section{Appraisal of Bishop Wale Oke's view}

Oke's understanding of one's hands as the means of wealth acquisition stems from the fact that it is the part of the human body that is used actively to work. This insight perhaps cuts across many cultures. It is noteworthy that all the scripture passages cited to support his idea of what hands connote, all come from the Old Testament. The Hebrew word that is

2. The bold is the original author's 
translated as hand is $\mathrm{T}$ ' and is often used in a figurative sense to mean strength and power. Oke's interpretation of hand as depicting economic capability is therefore an extension of this nuance. ${ }^{3}$ However, to say that Jesus' hands were pierced so that the believer's hands may be blessed seems quite unnecessary in his interpretive bid, for it does not really build up his argument. For his story of how poverty came into the world was the cursing of the ground at the fall of Adam, it had nothing to do with Adam's hands per se. If Jesus' suffering and death was to be a recovery of the paradise lost, does it really matter from which part of Jesus' body the blood flowed?

Secondly, the assumption that economic hardship came as a result of the Fall would suggest that only Christians could be rich. However, this is contradicted empirically as there are many rich people that are not Christians. The richest Nigerian is Alhaji Dangote, a Muslim.

\section{Bishop David Oyedepo}

Born on 27 September 1954, Bishop David Olaniyi Oyedepo is the founder of the David Oyedepo Ministries International (DOMI), a renaming of the Faith Liberation Hour Ministries, which he began in 1981. Bishop Oyedepo is also the presiding Bishop of the Living Faith Church Worldwide, better known as Winners' Chapel, which was inaugurated in 1983 as the church arm of the ministry. In addition, he is the senior pastor of Faith Tabernacle, Canaanland, a 560-acre land facility in Ota, south western Nigeria. The church seats 50000 worshippers at a time. The ministry known as DOMI is a formidable phenomenon boasting of a University known as Covenant University, secondary and primary schools, several business outfits, church branches all over Africa and overseas and another university in the founder's home state, Kwara (Kuponu 2007:39).

Born again in 1969, Bishop Oyedepo received the Holy Spirit baptism in 1975 (Kuponu 2007:18, 26). Always careful to date his experiences and the benchmarks of his ministries, Oyedepo recounts that his call to ministry was on 1 May 1981 when he received what he calls the liberation mandate. This was his launching pad into ministry. On 26 August 1987, he received the prosperity mandate while attending a conference in the US. Talking more about this mandate to this researcher, Oyedepo recalls that he was to speak at a conference organised by Fred K.C. Price that morning when in the course of having his morning devotion he received the mandate, 'Arise, go home and make my people rich'. As a result of this message, and with a heavy heart at having to disappoint Fred Price, a bosom brother, he cancelled his speaking engagements and went back home as commanded. On getting home in Nigeria, he began conducting Breakthrough Business Seminars in hotels; the aim of which was to 'address business people on biblical principles for breakthrough in their businesses'. This was later renamed Breakthrough Seminars and it expanded to include all categories of people, not just business people 'to open the eyes of understanding of the people to the covenant of blessings so that they can engage it in their own lives and see God's hand at work in their lives'. ${ }^{4}$ Today, Bishop Oyedepo is well-known as a prosperity gospel preacher, an accolade that he rejects (Oyedepo 2005:14).

Bishop Oyedepo's prosperity mandate in 1987 follows on the heels of the understanding of prosperity that he received while reading Gloria Copeland's book, God's will is prosperity, with his Bible in hand back in March 1981 during a threeday search (Oyedepo 2005:145, 155). Since then Oyedepo has written extensively and articulately on the subject matter.

\section{Oyedepo's views on prosperity}

A working premise on which Bishop Oyedepo's (2006) teaching on prosperity hangs is that prosperity is part of the atonement; and the major text for this is 2 Corinthians 8:9:

Riches is also part of our seven-fold redemptive heritage. Jesus also received for us riches. That's why the Bible says in 2 Corinthians $8: 9 \ldots$ Redemption is a cure for poverty, as it gives you access to the cure for poverty. When you were saved, you were redeemed from the plague of poverty, because your Father is very wealthy ... Jesus said, 'In my Father's house are many mansions: if it were not so, I would have told you' (Jn 14:2). There are no houses in heaven, only mansions. There are no boys' quarters or bungalows either, only mansions. That gives you an idea of the kind of riches you inherited from your Father. They were earlier stolen from you, but Jesus restored them back to you by His death and resurrection! But what must I do to be enriched? Covenant practice is the answer! Riches answer only to covenant practice. It is covenant practice that entitles you to economic empowerment. Deuteronomy 8:18 ... If you are not a covenant practitioner, you may live and die in church, yet your economic status will not change. (pp. 76-77)

At another instance of explaining his understanding of 2 Corinthians 8:9, Oyedepo (1992) states:

Jesus descended from his throne, to take us into glory, thereby making wealth a part of our redemption package. Jesus did not only come to save us from $\mathrm{sin}$, He also came to rescue us from the consequences of sin, prominent among which is poverty ... So, one of the principal consequences of sin is poverty. No wonder, the Son of God came, He made it part of his business to restore the dignity of wealth back to humanity. (p. 36)

In another book, Oyedepo (2005) asserts:

I am redeemed to be enriched! So I will be an abuse to redemption if I don't actualize that dimension of my redemption ... I'd like you to say and believe this: 'I am saved to display his wealth! I am on the right side! I am not a goat! So wealth is my heritage, abundance is my birthright' Friend, you are saved to display his wealth on the earth! To clothe the naked, feed the hungry and attend to the sick! That's what you are sent to do! (Matt.25:34-40) ... Prosperity is our identity. If you don't demonstrate it, then you are a misfit in the kingdom. (pp. 16-17)

\section{Appraisal of Bishop Oyedepo's view on prosperity}

The understanding of Oyedepo, like the previous preacher, is that the poverty that Jesus experienced while on earth was 
vicarious. Just as Jesus died on our behalf so did Jesus become poor on our behalf, just as he took our sins and gave us his righteousness, so did he take our poverty and give us his riches. The main phrase that seems to inform this understanding is: 'because of you' $\delta 1 \alpha$ v $\mu \alpha$. According to Louw and Nida $(1988,1: 804)$, the preposition $\delta 1 \alpha$, when followed by a noun or pronoun in the accusative serves as 'a marker of a participant constituting the cause or reason for an event or state'. For this reason it is often translated as because of, on account of, or for this reason. In the context at hand, the phrase could be translated as because of you, or on account of you. Can this phrase also suggest vicarious action? There are three occurrences of this type of $\Delta t \alpha$ + accusative phrase in 2 Corinthians:

3:7 $\delta 1 \alpha \tau \eta \nu \delta o \xi \alpha \nu \tau o v \pi \rho \circ \sigma \omega \pi$ ov - 'because of the glory of his face'

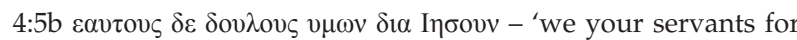
Jesus' sake'

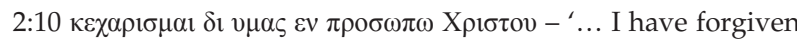
in the sight of Christ for your sake'

The phrase does not suggest vicarious action; all it does suggest is a reason why something happens, results, or exists (because of), or it refers to the beneficiary of an action (e.g. 'for your sake'), as Louw and Nida (1988, 1:803) assert: 'a marker of a participant who is benefited by an event or for whom an event occurs - "for the sake of or on behalf of, for the benefit of"'".

Furthermore, one can deduce from the first quotation above that being a Christian is not a guarantee to being rich, for Oyedepo (2006:77) makes mention of the need to be a 'covenant practitioner'. He (Oyedepo 2006) explains this to mean being a giver:

Solomon loved the Lord, he gave to the Lord. As a result, when the covenant was established, he was supernaturally empowered for inexplicable wealth. He gave, and then the heavens opened. If you are not a giver, the heaven over you won't open ... Job was also a giver, and he became the greatest of all the men in the east. Being a covenant practitioner is the only way to enduring wealth, as every other means of acquiring riches is time-tagged. (p. 78)

Therefore, if being a Christian is not a sufficient reason for one to be rich, because one must in addition be a giver, then the argument that prosperity is part of the atonement cannot be sustained.

\section{Pastor Enoch Adejare Adeboye}

Pastor E.A. Adeboye is the General Overseer (GO) of the Redeemed Christian Church of God (RCCG). He was formerly a lecturer of Mathematics in one of Nigeria's universities. Pastor E.A. Adeboye is the most-sought after Pentecostal preacher in Nigeria. His church, RCCG, grew under his leadership from just 39 parishes in the whole country in $1980^{5}$ to 4000 parishes in Lagos State only and the church is found in 109 nations by 2008 (Adeboye 2008:38). Pastor Adeboye is

5. That was when the founder of RCCG, Revd. Akindayomi died. not the founder of RCCG in contradistinction to the other two pastors discussed above. He was attracted to the church by the reputation of the then founder, Reverend Akindayomi, as a powerful minister of God. It was at a time of a personal crisis in his family in 1973 (Asonzeh 2008). RCCG grew out of Cherubim and Seraphim (C\&S), an Aladura church, where Reverend Akindayomi was a notable seer, Woli. The emphasis of the church was prayer, holiness and prophecy. Adeboye got saved on 29 July 1973 and became a pastor in 1975. He served the church as the interpreter of Reverend Akindayomi, translating his message to English. At the death of the founder in 1980, Pastor Adeboye became the head of a church with meager resources. As he recounts: the monthly income of the church was 6000 Naira, which hardly paid the salaries of the 40 people on the staff of the church. Adeboye, concerned for the growth of the church, travelled to Korea and the USA to meet with successful ministers and glean from their experience. ${ }^{6}$ The turnaround of the church came about in the nineties with the influx of educated people in the church through an arm of the church called Christ the Redeemer's Friends Universal, the slogan of which is 'Reaching the High and Mighty for Jesus Christ' (Asonzeh 2008:125). Today, RCCG is a colossus of an empire with interests in economic empowerment through its many arms such as Christ the Redeemer's Ministry (CRM), an outfit that initially started as an evangelistic arm of the church but which now manages the business interests of the church (Asonzeh 2008:123). With business interests spanning sectors such as education, banking, media, confectionary and so on, RCCG has transcended the dreams of its founder, who shunned wealth and never collected offertory from church members (Asonzeh 2008:152).

Pastor E.A. Adeboye is highly respected in Nigeria; he has endeared himself to many who view him as a humble man of God. He refuses to be called Doctor Adeboye, though he has a PhD in Mathematics. While the founder of the church took the title of a Reverend, Adeboye prefers to simply be called a pastor like all other pastors in the church. In addition, he is known for his simple dressing, usually a safari suit or a French cut, in a context where Nigerian pastors often adorn themselves gorgeously with flowing agbada.?

\section{Adeboye's views on prosperity}

Pastor Adeboye has written on prosperity and often makes allusion to it in his other writings that are not particularly on prosperity. Adeboye often recounts his very humble background, where he never got to wear shoes until he was 18 years old. He has experienced poverty firsthand and considers it a curse.

Given his background in a strictly holiness RCCG, Pastor Adeboye's first writing on prosperity is partly an apologetic for prosperity, How to turn your austerity into prosperity. Most

6.Adeboye's sermon at the Holy Ghost Night of 08 January 2010.

7. Agbada is a piece of clothing worn mainly by Yoruba males and male Northerners, (though other Nigerian groups nowadays wear it too). It is a free flowing robe. It is usually worn on grand occasions by older males or respected men in the society. Samuel Johnson (1921:111) describes it as follows: 'it reaches as far as the ankles, much embroidered at the neck and breast, open at the sides, and quite covers the arms'. 
of his writings on prosperity are usually character studies of some Bible personalities from whom he distils principles that should be applied in the contemporary context. Adeboye's discourse of prosperity may not be as well articulated and argued as Oyedepo's, but he is concise and clear about his rejection of poverty. He notes that people (Christians) reject prosperity because of fear of robbers and assassins. He pleads that none should reject prosperity (Adeboye 1989:1). On the positive side, he (Adeboye 1989) affirms that God is rich for the whole earth belongs to him including all the gold and silver (Ps 24:1, Hg 2:8). In addition, God's friends (Abraham, Isaac and Jacob) are like him, they are also rich:

God is the God of the rich, and his closest friends are very wealthy. Therefore, if you become one of the closest friends of God, you become very rich. If it is evil to be rich, it follows that God must be evil, but God is NOT evil. ... Birds of the same feathers flock together. The rich are friends of the rich, the poor are friends of the poor. Therefore, God decided to befriend the rich (pp. 2-3)

Furthermore, in Adeboye's (1989) discussion of 2 Corinthians $8: 9$, he refers to the vicarious nature of Jesus' death and suffering while on earth. If one accepts one gift, one should accept the other as well:

He died so that we can live. He was beaten, so that we might be healed ... He went to hell, that we may not go there. He thirsted, so that we may not thirst. If you do not want the wealth that the poverty of Jesus has purchased for you, then you must refuse his salvation that his death has also purchased for you. You must refuse his health that his stripes have purchased for you. If you receive his salvation that his death bought for you, it follows that you must receive his wealth that his poverty purchased for you. (p. 4)

Adeboye, by copious references to Scripture, asserts that prosperity as God's will for his people is an incontestable fact.

\section{Relationship between the Fall and atonement}

From the preachers' views sampled above, the Fall plays a prominent role in their understanding of the state of humans. Generally, atonement in the Old Testament is not described in relation to the Fall. It is rather described in relation to individual sins and community sins and states of uncleanness. There appears to be a general understanding that humans are sinful or unclean and contaminate whatever they come in contact with. This therefore leads to the need for atonement to be made even for non-living things like the altar (Lv 16:16-18).

In the New Testament, the understanding that individuals sin as a result of the transgression of Adam is basically Pauline and this is found most prominently in Romans 5:12-19:

therefore just as sin entered the world through one man, and death through sin, and in this way death came to all men, because all sinned ... for just as through the disobedience of the one man the many were made sinners so also through the obedience of the one man the many will be made righteous.
The New Testament, is in agreement with the Old Testament about the sinfulness of humans, but it takes the discussion further by tracing the origin of sin in humans to Adam. According to McGrath (1995:371), the Fall is a term that is used to describe an array of understanding concerning human nature in relation to sin. He posits that the image of a fall, although not strictly biblical in itself, brilliantly conveys the idea that creation now exists at a lower level than that intended for it by God. Therefore, atonement is the means of restoring humans to the state that was before the fall, that is, having a right relationship with God.

However, the view that Jesus has come to reverse all the evil brought by the Fall is, as expressed by the preachers, not attested in the New Testament. Indeed, it is speculative to assert that the Fall was responsible for the presence of sickness, death, evil and suffering in the world. Even if the Fall was responsible for all the ills in the world, it is clear that the atonement of Christ has not eradicated all these problems, for Christians at least do die. This leads to an appreciation of the understanding that the kingdom is 'already' and 'not yet' (Ladd 1974). This is the bane of Neo-Pentecostalism: it projects all the blessings of the 'world to come' as a present reality to be experienced in the now, thus tending towards an overrealised eschatology.

\section{Conclusion}

This article looked at some preachers' understanding that prosperity is part of the atonement. Their understanding was influenced by their taking the phrase $\delta 1 \alpha$ v $\mu \alpha \varsigma$ as denoting vicarious action. This phrase, however, does not support such interpretation. The article also found that a literary reading of the text shows the intention of Paul to present Jesus as a model for the Corinthians to emulate with regard to his sacrificial giving of himself. However, the fact that Paul used the terms riches and poverty in the bid to promote giving, seems deliberate and strategic for it was perhaps meant to elicit in the Corinthians an impression that they were rich enough to contribute to the needs of others.

In answer to the question whether 2 Corinthians 8:9 suggests that prosperity is part of the atonement, the article asserts that this understanding was definitely not in the mind of Paul, and it is not part of the atonement. Atonement refers to the death of Jesus on the cross to reconcile humans to God. People like Abraham, Job, Solomon and others have been wealthy since ages past. There was, therefore, no need for Jesus to die in order to accomplish the same.

\section{Acknowledgements Competing interests}

The author declares that she has no financial or personal relationships which may have inappropriately influenced her in writing this article. 


\section{References}

Adeboye, E., 1989, How to turn your austerity to prosperity, CRM, Lagos. Adeboye, E., 2008, Time of favor, ERA Communications, Lagos.

Asamoah-Gyadu, K., 2005, "Born of water and the spirit": Pentecostal/Charismatic Christianity in Africa', in O. Kalu (ed.), African Christianity: An African story, pp. 388-409, Department of Church History, University of Pretoria, Pretoria.

Asonzeh, U., 2008, A new paradigm of Pentecostal power: A study of the Redeemed Christian Church of God in Nigeria, Africa World Press, Trenton.

Barnett, P., 1997, The new international commentary on the New Testament: The second epistle to the Corinthians, Eerdmans, Grand Rapids.

Belleville, L., 1996, 2 Corinthians, InterVarsity, Downers Grove. (IVP New Testament series). Brown, F., Driver, S. \& Briggs, C. (eds.), 1906, Hebrew and English Lexicon, Hendrickson, Massachusetts.

Erickson, M., 1998, Christian Theology, 2nd edn., Baker Books, Grand Rapids.

Gifford, P., 1998, African Christianity: Its public role, Hurst, London.

Harris, M., 2005, The international Greek Testament commentary: The second epistle to the Corinthians, Eerdmans, Grand Rapids.

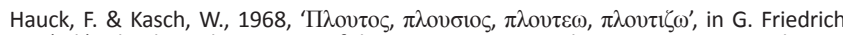
(ed.), Theological Dictionary of the New Testament, vol. 6, pp. 318-332, Eerdmans, Grand Rapids.

Johnson, S., 1921, The history of the Yorubas: From the earliest times to the beginning of the British protectorate, SCM, London.

Kalu, O., 2008, African Pentecostalism: An introduction, Oxford University Press, Oxford. Kuponu, I., 2007, 'The Living Faith Church (Winners Chapel), Nigeria: Pentecostalism, prosperity gospel and social change in Nigeria', Unpublished PhD dissertation, Faculty of Theology, University of Bayreuth, Bayreuth.
Ladd, G., 1974, A theology of the New Testament, Eerdmans, Grand Rapids.

Louw, J. \& Nida, E., 1988, Greek-English lexicon of the New Testament based on semantic domains, vol. 1, United Bible Societies, New York.

Malina, B. \& Neyrey, J., 1991, 'Honor and shame in Luke-Acts: Pivotal values of the Mediterranean world', in J. Neyrey (ed.), The social world of Luke-Acts: Models for interpretation, pp. 25-65, Hendrickson, Peabody.

Marshall, R., 2009, Political spiritualities: The Pentecostal revolution in Nigeria, University of Chicago Press, Chicago.

McGrath, A.E., 1995, 'Fall', in D.J. Atkinson \& D.H. Field (eds.), New dictionary of Christian ethics and pastoral theology, pp. 371-372, InterVarsity, Leicester.

Ojo, M., 1986, 'The growth of campus Christianity and charismatic movements in Western Nigeria', Unpublished PhD dissertation, Faculty of Theology, King's College, University of London, London.

Ojo, M., 2006, The end-time army: Charismatic movements in modern Nigeria, Africa World Press, Trenton.

Oke, W., 1999, The precious blood of Jesus, Eagle, Surrey.

Oyedepo, D., 1992, Covenant wealth, Dominion Publishing House, Ota.

Oyedepo, D., 2005, Understanding financial prosperity, Dominion Publishing House, Ota.

Oyedepo, D., 2006, Possessing your possessions, Dominion Publishing House, Ota.

Thrall, M., 2004, International critical commentary: 2 Corinthians, vol. 2, pp. 8-13, Clark, Edinburgh.

Togarasei, L., 2011, 'The Pentecostal gospel of prosperity in African contexts of poverty: An appraisal', Exchange 40, 336-350. http://dx.doi. org/10.1163/157254311X600744

Tuckett, C., 1992, 'Atonement in the NT', in D.N. Freedman (ed.), The Anchor Bible dictionary, vol. 1, pp. 518-522, Doubleday, New York. 